\title{
ANTIBODY POLYCLONAL PRODUCTION ON RABBIT ANTI-OVINE PREGNANCY-ASSOCIATED GLYCOPROTEIN (Rabbit anti-ovPAG)
}

\author{
E.T. Setiatin ${ }^{1,2}$, D. Sajuthi ${ }^{2,3}$, B. Purwantara ${ }^{2}$, C. Talib $^{4}$, F. Fathul ${ }^{5}$, U. Adiati ${ }^{4}$ and W. Praira $^{6}$ \\ ${ }^{1}$ Faculty of Animal Agriculture, Diponegoro University, Semarang, \\ Tembalang Campus, Semarang 50275 - Indonesia \\ ${ }^{2}$ Faculty of Veterinary Medicine, Bogor Agricultural University, \\ Jl. Agatis, Darmaga Campus, Bogor 16680 - Indonesia \\ ${ }^{3}$ Faculty of Mathematic and Sciences, Bogor Agricultural University, \\ Jl. Agatis, Darmaga Campus, Bogor 16680 - Indonesia \\ ${ }^{4}$ Center Research Institute of Animal Sciences, \\ Jl. Raya Pajajaran Kav. E59, Bogor - Indonesia \\ ${ }^{5}$ Faculty of Agriculture, Lampung University, \\ Jl. Sumantri Brojonegoro No. 3 Bandarlampung - Indonesia \\ ${ }^{6}$ Primate Research Institute, Jl Lodaya, Bogor 16151 - Indonesia \\ Corresponding E-mail: etsetiatin@gmail.com
}

Received April 27, 2011; Accepted July 30, 2011

\begin{abstract}
The aim of the study was to produce polyclonal antibody (rabbit anti-ovPAG) which could detect PAG in the urine of pregnant ewes. Twelve rabbits were immunized against ovPG DEAE-TrisHCl (DT), DEAE-NaCl 20mM (DN2), DEAE-NaCl 40mM (DN4), DEAE-NaCl 80mM (DN8), DEAE-NaCl $160 \mathrm{mM}$ (DN16), DEAE-NaCl 320mM (DN32) and DEAE-NaCl 1M (DN1) and $\mathrm{NaCl} 0.9 \%$ as a placebo. The $0.5 \mathrm{ml}$ of isolate (purified from ovine cotyledon) was emulsified in equal volume with complete and incomplete Freud's adjuvant. The mixture of each isolate and adjuvant was injected at mutiple sites along the dorsal area of rabbits by subcutaneous route. Blood were collected from marginal ear vein, starting before first injection (baseline) and every 14 days. Rabbit anti-ovPAG were measured using Modified ELISA Technique. By using Western Blot Technique, DN32 showed the best immune response among others and also could differenciate ovPAG in the urine of pregnant ewes It could be concluded that ovPAG DN32 is a specific source of rabbit anti-ovPAG production. Protein of ovPAG at molecular weight $31 \mathrm{kDa}$ is a pregnancy protein marker of garut sheep and could be developed as a major protein for producing antibodi.
\end{abstract}

Keywords : cotyledon, ELISA, ovPAG, polyclonal antibody, rabbit anti-ovPAG

\section{INTRODUCTION}

Pregnancy-associated glycoprotein (PAG) is a member of aspartic proteinase family secreted from trophoblastic nucleic acid (Wooding, 1992; Perẻnyi et al., 2002; El Amiri et al., 2003; Hughes et al., 2003) that are expressed in the outer epithelial cell layer (chorion or trophectoderm) of the ungulate placenta (Green et al., 2000; El Amiri et al., 2004). Pregnancy-associated glycoprotein could be detected in blood using radioimmuno assay (RIA) at the attachment of placenta during development of fetomaternal sincysium ( Ranilla et al., 1994; Verberckmoes et al., 2004). Of this, PAG could be used as pregnancy indicator and also feto-placental wellbeing (Karen et al., 2003; Boscos et al., 2003).

Molecular mass of protein purified from garut sheep cotyledon is $30.8 \mathrm{kDa}$ smaller than $\mathrm{El}$ Amiri et al. (2004) did on sheep foetal cotyledons at 55-65 kDa. Some ovPAG were gained during purification namely DEAE-TrisHCl (DT); DEAE$\mathrm{NaCl} 20 \mathrm{mM}$ (DN2) ; DEAE-NaCl 40mM (DN4); DEAE-NaCl 80mM (DN8); DEAE-NaCl 160mM (DN16); DEAE-NaCl 320mM (DN32) and DEAE-NaCl 1M (DN1). From these, two of them were chosen as ovPAG sources on producing polyclonal antibody (anti-ovPAG), namely DN16 and DN32 (Setiatin et al., 2009).

Polyclonal antibody was produced by 
injecting purified ovPAG mentioned above, through rabbit subcutaneously (Ayad et al., 2007). Polyclonal antibody could detect the biological material bounding on PAG (Green et al., 2005). Therefore, rabbit anti-ovPAG could be used as the agent for detecting PAG in the urine. Rabbit antiovPAG determined using monogel SDS-PAGE method followed with Western Blot. This method was applied for detecting the polyclonal antibody in blood (Barbato et al., 2007; Bella et al., 2009) whereas its concentration was measured using modified ELISA technique.

The aim of the study was to produce polyclonal antibody (rabbit anti-ovPAG) which could detect PAG in the urine of pregnant ewes

\section{MATERIALS AND METHODS}

\section{Polyclonal Antibody Production}

There were 12 NZW rabbit divided into 6 groups based on ovPAG sources (Table 1) gained through ovPAG purification of cotyledon extract through Sephadex-G75 and DEAE-cellulose column, namely S, DT, DN8, DN16 and DN32 (Setiatin et al. 2009). Before immunization, all isolates were prior to Freud's complete adjuvant (Sigma $\left.{ }^{\circledR}\right)$ and Freud's incomplete adjuvant (Sigma ${ }^{\circledR}$ ) to bound ovPAG (Goldsby et al., 2000; Erb and Hau, 1994; Hendriksen and Hau, 2003).

There were four types of blood, namely baseline collected before first immunization (B), FCA, FICA1 and FICA2. Ovine PregnancyAssociated Glycoprotein (ovPAG) was immunized subcutaneously through back of NZW rabbit. At first immunization, each rabbit in every group had the mixture of $0.5 \mathrm{ml}$ of isolate and 0.5 $\mathrm{ml}$ of Freud's complete adjuvant called FCA (Sigma $\left.{ }^{\circledR}\right)$. At the $14-d$, the first booster contained $0.5 \mathrm{ml}$ isolate and $0.5 \mathrm{ml}$ of Freud's incomplete adjuvant called FICA1 (Sigma $\left.{ }^{\circledR}\right)$. Two weeks after that, rabbit had second booster, immunized with the same composition called FICA2. Clearly, every two weeks, bloods were taken by disposable syrink into anticoagulant glass. Blood was collected through $A$. auricularis and $V$. auricularis with maximum volume was $20 \%$ of body weight. (Ayad et al., 2007).

There were four types of blood namely Baseline collected before first immunization (B), FCA, FICA1 and FICA2. Samples were centrifuged at 2,500 rpm for 15 minutes, then the blood plasma was collected and stored at $-20^{\circ} \mathrm{C}$ After this, rabbit anti-ovPAG was measured using modified ELISA.

\section{Measurement of Rabbit anti-ovPAG Concentration using Modified ELISA Technique}

Isolate ovPAG namely S, DT, DN8, DN16 and DN32 were added with carbonate-bicarbonate buffer (coating-buffer) at 1:10. It was added with $100 \mu \mathrm{l}$ at every well, then was incubated at $4^{\circ} \mathrm{C}$ overnight. The plate was washed by PBS Tween $0.1 \%$ four times. Blotto $5 \%$ (5 g skim milk added with PBS $0.1 \%$ ) was filled into every well at 300 $\mu \mathrm{l}$, and was incubated at $37^{\circ} \mathrm{C}$ for 60 minutes (Silva et al., 2007). Then, plate was washed with PBS Tween $0.1 \%$ four times (Crowther, 2001; Green et al., 2005; Silva et al., 2007).

Simultaneously, rabbit anti-ovPAG was diluted in blotto $5 \%(1: 50)$, it was added with $100 \mu \mathrm{l}$ blotto $5 \%$ into every well, then was incubated at room temperature for 90 minutes. After washing the plate, every well was added with $100 \mu \mathrm{l}$ the mixture Goat anti-rabbit IgG peroxidase (Sigma $\left.{ }^{\circledR}\right)$ in blotto $5 \%$ (1:2000), and it was incubated at $37^{\circ} \mathrm{C}$ for 60 minutes. ELISA plate was washed with PBS Tween $0.1 \%$ four times.

The next step, every well was filled with 100 $\mu 1$ TMB or 3.3', 5.5' tetra methyl benzidine dihydrochloride (Sigma ${ }^{\circledR}$ ), incubated at room

Table 1. Ovine Pregnancy Associated Glycoprotein and Its Concentration to New Zealand White Rabbit

\begin{tabular}{lcc}
\hline \multicolumn{1}{c}{ ovPAG Sources } & Rabbit (n) & $\begin{array}{c}\text { Concentration } \\
(\mathrm{ng} / \mu \mathrm{l})\end{array}$ \\
\hline Sephadex-G75 (S1 \& S2) & 2 & 181.00 \\
DEAE-Tris HCl 0.01 M (DT.1 \& DT.2) & 2 & 171.00 \\
DEAE-NaCl 80 mM (DN8.1 \& DN8.2) & 2 & 2.67 \\
DEAE-NaCl 160 mM (DN16.1 \& DN16.2) & 2 & 44.33 \\
DEAE-NaCl 320 mM (DN32.1 \& DN32.2) & 2 & 86.00 \\
Control (C1 \& C2) & 2 & 0.00 \\
\hline
\end{tabular}


temperature for 20 minutes until the color became blue. The reaction was stopped using $50 \mu \mathrm{l} 2 \mathrm{~N}$ $\mathrm{H}_{2} \mathrm{SO}_{4}$ at every well. The changing color from blue to yellow indicated that the reaction finished. Optical density of yellow color was measured using Microplate Reader Model 3550 (Biorad®) at wavelength $450 \mathrm{~nm}$ (Crowther, 2001; Cho et al., 2003).

\section{Rabbit anti-ovPAG Determination using Western Blotting Technique}

Western Blotting Technique was applied to detect the specified reaction of rabbit anti-ovPAG to ovPAG in pregnant and nonpregnant urine of garut sheep. Urine was collected early in the morning and divided into alliquot, the ovPAG protein was separated by monogel SDS-PAGE vertical to molecular marker (Merck®) and subjected into Western Blotting. Protein migrated through running buffer and attached to the protein marker which had a proper molecular mass. Monogel SDS-PAGE was transfered into nitrocellulose membrane, washed with blotto 5\% for 60 minutes. Blotting was formed by rabbit anti-ovPAG DN32 (1:50), incubated overnight. After washing with PBS Tween $0.1 \%$, Western analysis by alkaline phosphatase (1: 5000) was incubated at $37^{\circ} \mathrm{C}$ for 60 minutes. After three times washing, nitrotetrazolium blue chlorine98\% (NBT) and 5-bromo-4-chloro-3-indolyl phosphate disodium salt (BICP) were added as standard substrates, then was incubated for 20 minutes, and washed again with $\mathrm{dH}_{2} \mathrm{O}$ (Goldsby et al., 2000; Barbato et al., 2007; Bella et al., 2009; Majewska et al., 2005; Huebner, 2004).

\section{Data Analysis}

Response immune and the specifity of rabbit anti-ovPAG were analyzed descriptively. Response immune was analysed by measuring the changing of optical density ovPAG to rabbit antiovPAG (B; FCA; FICA1, dan FICA2) gained during immunization. Based on response immune and total protein concentration, rabbit anti-ovPAG was chosen as an measuring ovPAG concentration in urine. Meanwhile, determination of rabbit antiovPAG to ovPAG in C; DN32; DN16; DN8; DT, and $\mathrm{S}$ collection during purification (Setiatin et al., 2009) also in the pregnant and nonpregnant urine were analysed based on the relative migration of protein ovPAG.

\section{RESULTS AND DISCUSSION}

Immunogen has specific criteria known as foreign agent, has large molecular mass, has a complex chemical structure, dose injection, route and time, antibody could attach to its epitop, and capable to produce specific immune response. Rabbits had been chosen to produce rabbit antiovPAG because of different species, easy to be handled, had never contact with ovPAG produced from cotyledone garut sheep. Ovine PregnancyAssociated of garut sheep has these criteria that is produced from different species, molecular weight was at $30.7-78 \mathrm{kDa}$, and never been injected to rabbit as antibody producer (Setiatin et al., 2009).

$\mathrm{B}$ and or T lymphocyte could be detected if rabbit be known the epitop. Epitop is active binding site antigen (ovPAG) which could attach to $\mathrm{B}$ and $\mathrm{T}$ receptors. Immune response produced related to injecting dose and route during immunization. When mixed antibody could determine more than one epitop, called polyclonal antibody (Goldsby et al., 2000; Abbas et al., 2007).

The strength interaction between antigen and antibody depend on their affinity. The higher affinity the stronger ability of antibody to bound of antigen and this bound would stay longer. Cross-reactivity appeared when two antigens have identical epitop or antibody had specific binding site for one epitop also bound to other epitop which had similar chemical structure (Huebner, 2004).

\section{Measuring Rabbit anti-ovPAG Concentration}

There were variation of immune response produced by rabbit $(\mathrm{n}=12)$ during immunization, therefore antibodies produced during research must be selected of their capability before using as polyclonal antibody sources. There were 11 rabbits had good response to ovPAG based on optical density measurement using modified ELISA. Baseline titer was stated as based titer before first ovPAG injection. To elevate immunogenicity of ovPAG, isolate was added with adjuvant. Complete adjuvant containing Mycobacterium sp in Freud's Complete Adjuvant (Sigma ()) obtained once at first immunization. Moreover, at second and third immunization, rabbits were injected with dilution of ovPAG and incomplete adjuvant. These could stimulate B and $\mathrm{T}$ cell to to produce immune response, called rabbit anti-ovPAG (Cruse and Lewis, 2002). 
First immunization would trigger B-cell for proliferation and differentiation of antibody secretion cell and memory cell on producing primary immune response. Some of antibody cells would migrate and stay in bone narrow at long time. Second immunization or Booster I and third immunization or Booster II would produce secondary immune response, their concentration were higher than first immunization. While memory cell of B cell was activated to produce large number of antibody because of $\mathrm{T}$ cell stimulation (Goldsby et al., 2000; Abbas et al., 2007).

There was important result that control group produced low optical density because they were immunized only with $\mathrm{NaCl} 0.9 \%$ while other groups were immunized with ovPAG produced immune response. These indicated that rabbit could react to ovPAG as foreign agent or antigen.

Figure 1 presents the comparison of antibody produced by DN16 and DN32. Although ovPAG DN32 and DN16 had similar protein weight at
30.86; 33.64, and $71.87 \mathrm{kDa}$, the protein band of DN32 had a the better criteria related to its intensity. Also, the concentration of total protein DN32 measured with Protein Assay was higher than DN16, that was $86.00 \mathrm{ng} / \mu \mathrm{l}$ and $44.33 \mathrm{ng} / \mu \mathrm{l}$, respectively. Of these, ovPAG DN32 was chosen as antigen source because it might produce a better immune response (rabbit anti-ovPAG DN32).

\section{Determination of rabbit anti ovPAG}

Western Blotting was applied to determine the ability rabbit anti ovPAG DN32 to bound ovPAG in cotyledon. Conjugated enzyme antiRabbit Alkaline Phosphatase has specific activity to lysis phosphate bounded in molecules. The number of phosphate bound could be read by added BICP and NBT substrates through nitrocellulose membrane. Protein band appeared in the membrane indicated there was specific reaction between rabbit anti ovPAG to ovPAG in the sample (Huebner, 2004).
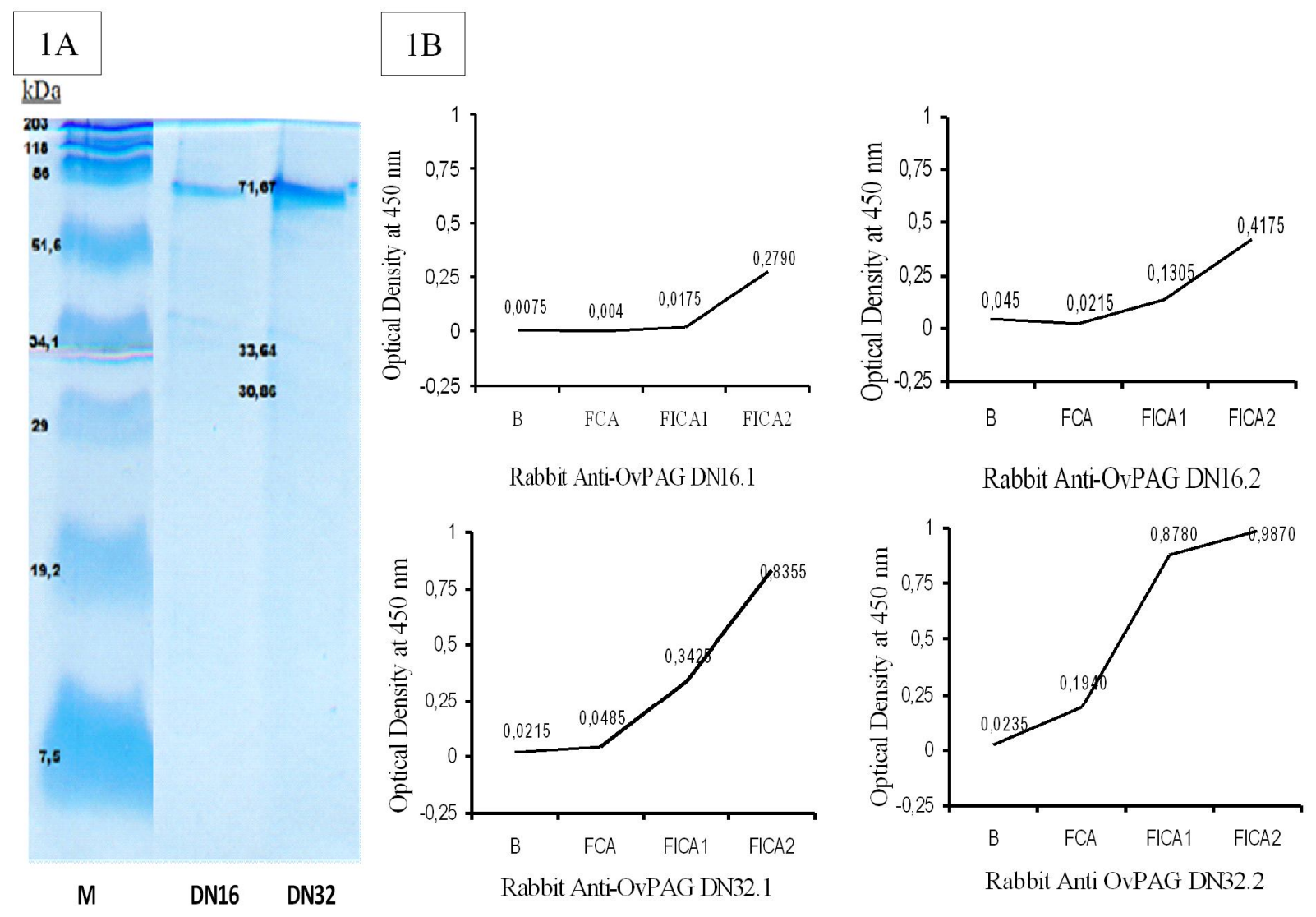

Figure 1. Comparison between DN16 and DN32 as Rabbit Anti-ovPAG. 1A= molecular weight; 1B = immune response. B: baseline antibody collected from blood plasma before first immunization, FCA: antibody at the first immunization, FCAl: antibody of the first booster; FCA2: antibody of the second booster. 


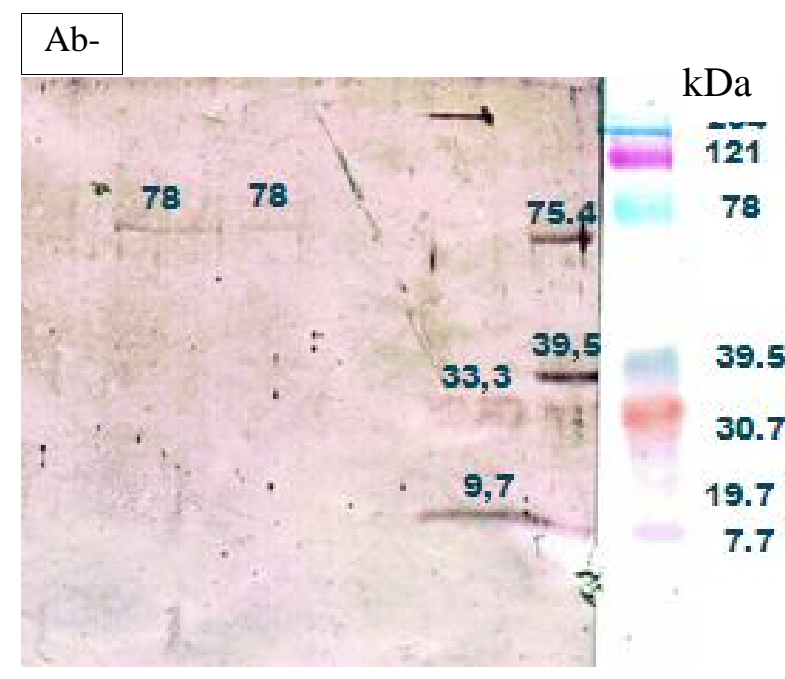

$\begin{array}{lllllll}\mathrm{K} & \mathrm{DN} 32 & \mathrm{DN} 16 & \mathrm{DN} 8 & \mathrm{DT} & \mathrm{S} & \mathrm{M}\end{array}$

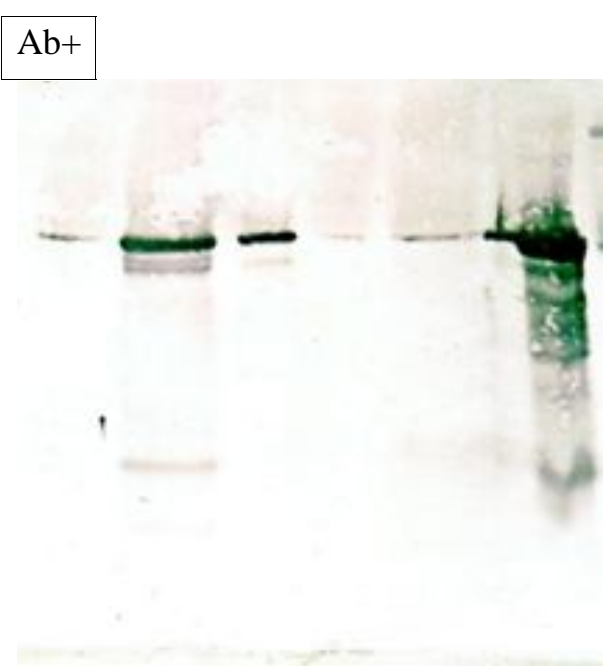

K $\quad$ DN32 DN16 DN8 DT $\mathrm{S}$

Figure 2. Determination of negatif ( $\mathrm{Ab}-)$ and positif $(\mathrm{Ab}+)$ rabbit anti-ovPAG DN32 to ovPAG source (K; DN32; DN16; DN8; DT; S). Rabbit's blood has spesific protein at $78 \mathrm{kDa}$.

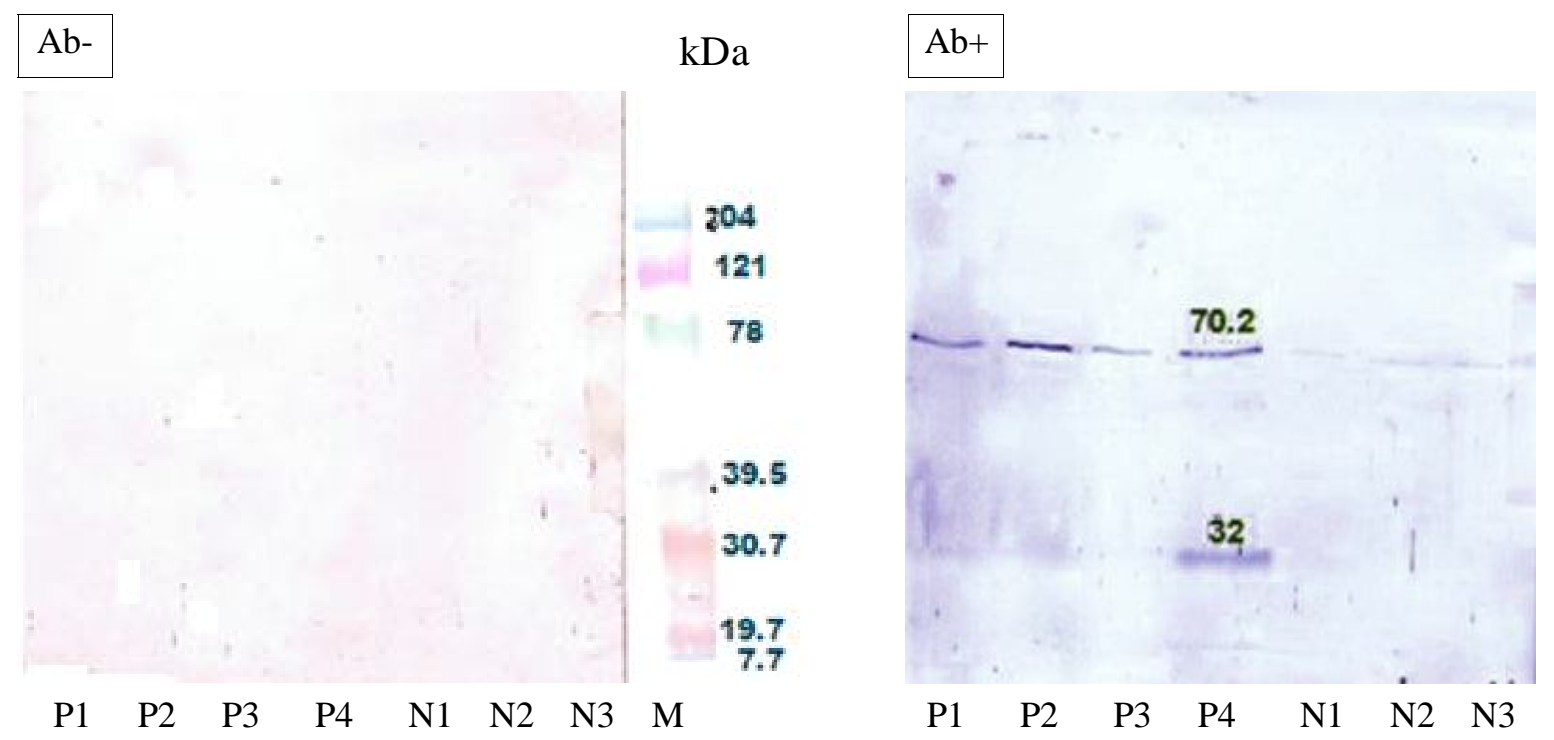

Figure 3. Determination of negative and positive rabbit anti-ovPAG DN32 to ovPAG in the pregnant and non pregnant urine of garut sheep $(\mathrm{P}=$ pregnant, $\mathrm{N}=$ non pregnant. $\mathrm{Ab}-$, No band appears or no response; $\mathrm{Ab}+$, Bands appear)

Negative rabbit anti-ovPAG was baseline antibody (B) collected from blood plasma before first immunization (Figure 1). There was no protein band and immune response in $\mathrm{K}$ group. This indicated that there was no immune response to $\mathrm{NaCl} 0.9 \%$. Isolate DN32 and DN16 had one band at $71 \mathrm{kDa}$ whereas DN8 did not have band although had high immune response. Moreover ovPAG DT had two bands at 31 and $14 \mathrm{kDa}$ also ovPAG S had three bands at 71, 34, and $14 \mathrm{kDa}$.
Positive Rabbit anti-ovPAG DN32 had been responded to all source of ovPAG at $71 \mathrm{kDa}$ with different intensity. This might occur because there were two antigens that had the same unidentical epitop, therefore one epitop could bound stronger than another (Huebner, 2004). Isolate ovPAG DN32 and DN16 had similar protein bands at 71 and $62 \mathrm{kDa}$, moreover ovPAG DN32 also had other band at $14 \mathrm{kDa}$. Isolate ovPAG $\mathrm{S}$ had five protein bands at $71,62,53,34$, and $14 \mathrm{kDa}$ 
(Figure 2). Based on these results, ovPAG DT, S, and DN8 could not be used as rabbit anti ovPAG sources because they had cross reaction. Protein at molecular weight $71 \mathrm{kDa}$ became general protein belong to rabbit because this protein could react to negative and positive rabbit anti ovPAG DN32.

Continuing determination of rabbit anti ovPAG DN32 was applied to ovPAG in pregnant and non pregnant urine of garut sheep. There was no reaction between negative rabbit anti ovPAG DN32 to ovPAG in the urine of pregnant and non pregnant ewes. Moreover, there were obvious band as the result of anti ovPAG to ovPAG in the urine. Both pregnant and nonpregnant group had similar protein band at $71 \mathrm{kDa}$. This indicated that this protein has belonged to the rabbit. An important result shown that ovPAG pregnant urine only bounded to rabbit anti ovPAG at $31 \mathrm{kDa}$ and in nonpregnant urine there was no reaction at all (Figure 3). Of this, protein with molecular weight at $31 \mathrm{kDa}$ could be used as pregnancy marker for garut sheep. A similar result reported by Setiatin et al. (2009) that protein resulted from purification and isolation of PAG from garut sheep cotyledon is $30.86 \mathrm{kDa}$.

Specific reaction between rabbit anti ovPAG DN32 to ovPAG in pregnant and nonpregnant urine could be used to differentiate pregnancy status of garut sheep. While, polyclonal antibody could be produced successfully from isolate ovPAG DN32, this study should be continued to produce more applicative pregnancy detection tools using modified ELISA Ttechnique.

\section{CONCLUSION}

Ovine Pregnancy-associated glycoprotein (ovPAG) DN32 is a specific source of rabbit antiovPAG production. Protein of ovPAG at molecular weight $31 \mathrm{kDa}$ is a pregnancy protein marker of garut sheep and could be developed as a major protein for producing antibodi.

\section{REFERENCES}

Abbas A.K., A.H. Lichtman, and S. Pillai. 2007. Cellular and Mollecular Immunlogy. $6^{\text {th }} \mathrm{Ed}$. Philadelphia : Elsevier Inc. pp. 3-142

Ayad, A., N.M. Sousa N.M., J. Sulon, M. IguerOuada and J.F. Beckers. 2007. Comparison of five radioimmunoassay systems for PAG mesurement: Ability to detect early pregnancy in cow. Reprod. Dom. Anim. 42(4):433-440
Barbato, O., N.M. Sousa, K. Klisch, E. Clerget, A. Debenedetti, V. Barile, A. Malfatti, and J.F. Beckers. 2007. Isolation of pregnancyassociated glycoproteins (PAG) from water buffalo (Bubalus bubalis) placenta by use of Vicia villosa bound agarose affinity chromatography. Italian J. Anim. Sci. 6 (Suppl. 2):762-765

Bella, A., N.M. Sousa, M. Dehimi, J. Watts and J.F. Beckers. 2009. Western analyses of pregnancy-associaed glycoprotein family (PAG) in placental extracts of various mammals. Theriogenology 68(7):1055-1066

Boscos, C.M., F.C. Samartzi, A.G. Lymberopoulos, A. Stefanakis and S. Belibasaki. 2003. Assessment of progesterone concentration using enzymeimmunoassay for early pregnancy diagnosis in sheep and goats. Reprod. Dom. Anim. 38(3):170

Cho, Y.A., Y. J. Kim, B.D. Hammock, Y.T. Lee and H.S. Lee. 2003. Development of a microtiter plate ELISA and a dipstick ELISA for the determination of the organophosphorus insecticide fenthion. J Agric. Food Chem. 51:7854-7860

Crowther, J. R. 2001. The ELISA Guidebook. New Jersey : Humana Press. pp. 1-82

Cruse, J.M. and R.E. Lewis. 2002. Illustrated Dictionary of Immunology. $2^{\text {nd }}$ Ed. New York : CRC Press.

El Amiri, B., B. Remy , N.M. Sousa, B. Jorris, N.G. Ottiers, Z. Perẻnyi, H.B. Mboko and J.F. Beckers. 2003. Isolation and partial characterization of three pregnancyassociated glycoproteins from the ewe placenta. Mol. Reprod. Dev. 64:199-206.

El Amiri, B., B. Remy, N.M. Sousa and J.F. Beckers. 2004. Isolation and characterization of eight pregnancyassociated glycoproteins present at high levels in the ovine placenta between day 60 and day 100 of gestation. Reprod. Nutr. Dev. 44:169-181

Erb, K. and J. Hau. 1994. Monoclonal and Polyclonal Antibodies. In : P. Svendsen and J. Hau (ed.). Handbook of Laboratory Animal Science. Vol-1. Boca Raton, Florida: CRC Press. pp. 293-309

Goldsby, R.A., T.J. Kindt and B.A.Osborne. 2000. Kuby Immunology. $4^{\text {th }}$ Ed. New York : WH Freeman \& Co. pp. 63-172

Green, J.A., S. Xie, X. Quan, B. Bao, X. Gan, N. 
Mathialagan, J.F. Beckers and R.M. Roberts. 2000. Pregnancy-associated bovine and ovine glycoproteins exhibits spatially and temporally distinct expression patterns during pregnancy. Biol. Reprod. 62:16241631

Green, J.A., T.E. Parks, M.P. Avalle, B.P. Telugu, A.L. McLain, A.J. Peterson, W. McMillan, N. Mathialagan , R.R. Hook, S.C. Xie and R.M. Roberts. 2005. The establishment of an ELISA for the detection of pregnancyassociated glycoproteins (PAGs) in the serum of pregnant cows and heifers. Theriogenology. 63(5):1481-1503

Hendricksen, C. and J. Hau. 2003. Production of Polyclonal and Monoclonal Antibodies. In: J. Hau and G.L. van Hoosier (ed.). Handbook of Laboratory Animal Science : Essential Principles and Practices. Volume 1. $2^{\text {nd }}$ Ed. Boca Raton, Florida : CRC Press. pp. 391-411

Huebner, J. 2004. Antibody-antigen interactions and measurements of immunologic reactions. In:G.B. Pier , J.B. Lyczak and L.M. Wetzler. (ed.). Immunology, infection, and immunity. Washington, D : ASM Press. pp. 207-232

Hughes, A.L, J.A. Green, H. Piontkivska and R.M. Roberts. 2003. Aspartic proteinase phylogeny and the origin of pregnancyassociated glycoproteins. Mol. Biol. Evol. 20(11):1940 - 1945

Karen, A., J.F. Beckers, J. Sulon., B. El Amiri, K. Szabados, S. Ismail, J. Reiczigel and O. Szenci. 2003. Evaluation of false transrectal ultrasonographic pregnancy diagnoses in sheep by measuring the plasma level of pregnancy-asociated glycoproteins. Reprod. Nutr. Dev. 43:577-586

Majewska, M., G. Panasiewicz, M. Dabrowski, Z. Gizejewski, J.F. Beckers and B. Szafranska. 2005. Multiple forms of PregnancyAssociated Glycoproteins released in vitro by porcine chorion or placentomal and interplacentomal explants of wild and domestic ruminants. Biol. Reprod. 5(2):185203.
Perẻnyi, Z., O. Szenci, P.V. Drion, H. BangaMboko, N.M. de Sousa, B. El Amiri and J.F. Beckers. 2002. Aspartic proteinase members secreted by the ruminant placenta: Specificity of three radioimmunoassay system for the measurement of pregnancyassociated glycoprotein. Reprod. Dom. Anim. 37:324-329.

Ranilla, M.J., J. Sulon, M.D. Mantecón and J.F. Beckers. 1994. Plasmatic profiles of pregnancy-associated glycoprotein and progesterone levels during gestation in churra and merino sheep. Theriogenology. 44:537-545

Setiatin, E.T., D. Sajuthi, B. Purwantara and C. Talib. 2009. Extraction and isolation of ovine pregnancy-associated glycoprotein (ovPAG) from cotyledon placenta of garut sheep. JITV 14(3):208-215

Silva, E., R.A.Sterry, Kolb, N. Mathialagan, M.F. McGrath, J.M. Ballam and P.M. Fricke. 2007. Accuracy of a pregnancy-associated glycoprotein ELISA to determine pregnancy status of lactating dairy cows twenty-seven days after timed artificial insemination. J. Dairy Sci. 90:4612-4622

Stryer, L. 1995. Biochemistry. $4^{\text {th }}$ Ed. New York: WH Freeman \& Co. pp. $875-910$

Verbeckmoes, S., L. Vandaele, S. de Cat, B. El Amiri, J. Sulon, L. Duchateau, A. de Kruit, J.F. Beckers and A. van Soom. 2004. A new test for early pregnancy diagnosis in sheep: Determination of ovine pregnancy associated glycoprotein (ovPAG) concentration by means of a homologous radioimmunoassay. Vlaams Diergeneeskundig Tijdschrift 73:119-127.

Wooding, F.B.P. 1992. Current topic: the synepitheliochorial placenta of ruminants: binucleate cell fusions and hormone production. Placenta. 13:101-113.

Zoli, A.P., J.F. Beckers, P. Wouters-Ballman, J. Closset, P. Falmagne and F. Ectors. 1991. Purification and characterization of a bovine pregnancy-associated glycoprotein. Biol. Reprod. 45:1-10 